研 究

\title{
h-BN/ 長石一複合焼結体の特性に及ぼす長石前処理溶解の効果
}

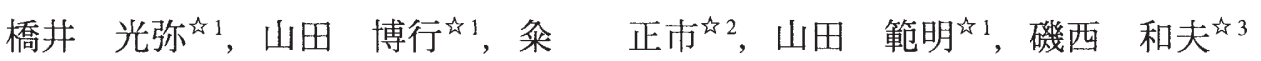 \\ 的1名古屋市工業研究所, 干 456-0058 名古屋市熱田区六番 3-4-41.

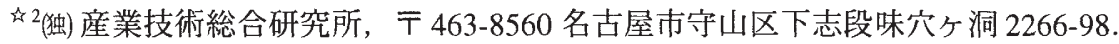 \\ 切 3 滋賀大学, 干 520-0862 大津市平津 2-5-1.
}

\section{Effect of Pre-melted Feldspar on the Property of h-BN/Feldspar Composite}

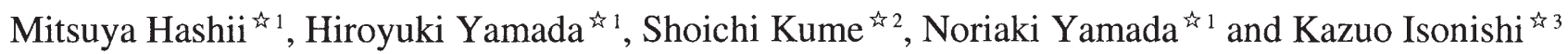 \\ ${ }^{2}$ 1 Nagoya Municipal Industrial Research Institute, 3-4-41 Rokuban, Atsuta-ku, Nagoya 456-0058, Japan. \\ ${ }^{4}$ National Institute of Advanced Industrial Science and Technology, 2266-98 Anagahora, Shimoshidami, Moriyama-ku, \\ Nagoya 463-8560, Japan. \\ ${ }^{23}$ Shiga University, 2-5-1 Hiratsu, Otsu 520-0862, Japan.
}

Received June 30, 2011

\begin{abstract}
SYNOPSIS
h-BN/feldspar composite was sintered without pressure at low temperature in air. $\mathrm{h}-\mathrm{BN}$ and feldspar powders were mixed at the volume ratio of $1: 1$. The h-BN powder contained 40 mass $\% \mathrm{~B}_{2} \mathrm{O}_{3}$. The feldspar was pre-melted and then milled. The melting point of as-received feldspar was nearly $1500 \mathrm{~K}$. The mixed powder was sintered without pressure at $1473 \mathrm{~K}$ in air. The bending strength of the compact was $59 \mathrm{MPa}$. This value was higher than that of the compact sintered using as-received feldspar. It was also higher value than that of the compact, which contained the pre-melted feldspar, sintered at $1573 \mathrm{~K}$. Additionally, it would be important using oxygen-enriched h-BN powder which contains $\mathrm{B}_{2} \mathrm{O}_{3}$ at not only the surfaces but also insides.
\end{abstract}

KEY WORDS

hexagonal boron nitride, feldspar, boron oxide, pressure-less sintering, low-temperature sintering

\section{1 緒 言}

六方晶窒化ホウ素 h-BN バルク材は，実用上有用な特徵を 多く備えており, 期待される適応例は数ある ${ }^{1-3)}$. 切削加工容 易ないわゆるマシナブルセラミックスとして注目されている. 熱衝撃に対する耐性が既存セラミックス中で最高値を示す4-7). 溶融金属に対する酎食性にも優れている ${ }^{5-8)}$.すなわち濡れ難 くかつ高融点の材料であるが,このことは難焼結性を意味す る. 通常は, 非酸化性霧囲気の下で $1900 \mathrm{~K}$ 以上 $($ 多くの場合, $2300 \mathrm{~K}$ 以上) の加圧焼結を要する.

条ら ${ }^{9}$ は, h-BN と長石を混合することで, h-BN/長石一複 合体の大気中・無加圧・低温焼結を実現した. h-BN系材料の 大気中焼結については他の報告例を見出せない. 彼らは, h-BN 粉末と長石粉末の界面に酸化物 $\left(\mathrm{B}_{2} \mathrm{O}_{3}\right)$ が介在することで焼結 中での原料粉末間の濡れ性が改善されることを確認した.

続いて，著者らの一部 ${ }^{10)}$ は, $\mathrm{B}_{2} \mathrm{O}_{3}$ を原料として h-BNが製 造される場合が多いことに着目した，通常の市販 h-BN粉末 の範囲を大幅に超えて高濃度に $\mathrm{B}_{2} \mathrm{O}_{3}$ を含有する高酸素 $\mathrm{h}-\mathrm{BN}$ 粉末を原料とすることで, $\mathrm{h}-\mathrm{BN} /$ 長石一複合体の強度を大幅
に向上させた．具体的には， $\mathrm{B}_{2} \mathrm{O}_{3}$ を約 40 mass\% 含有する高 酸素h-BN粉末を原料とし, 融点が約 $1500 \mathrm{~K}$ の曹長石を $\mathrm{h}-\mathrm{BN}$ 原料と同体積率となるように混合後, 圧粉して, $1573 \mathrm{~K}-3.6$ ks (昇温および降温速度: $5 \mathrm{~K} / \mathrm{mim}$ ) の大気中・無加圧焼結を することで, 曲げ強度 $47 \mathrm{MPa}$ の焼結体を得た. その際, 焼結 過程の溶融 $\mathrm{B}_{2} \mathrm{O}_{3}$ による濡れの多少が, 焼結体強度の大小を左 右する，すなわち， $\mathrm{B}_{2} \mathrm{O}_{3}$ を多量に含むことが，焼結体強度の 向上につながる。

本報告は，その第 2 報である．前報 ${ }^{10)}$ の研究では，桑ら99 によるオリジナルの成果を基盤として, h-BN 原料を変更す ることで焼結体強度を向上させた. 本研究では, 長石原料に 前処理を施すことで, 焼結体のさらなる強度向上を目指した。 具体的には, 焼結前処理として, 長石を加熱溶解後に冷却固 化したものを粉砕し, これを高酸素 h-BN粉末と混合して焼 結に供した. 前報 ${ }^{10)}$ の作製法では, 長石は焼結過程で初めて 溶解し, その際にガスが発生し, そのことが焼結体密度を低

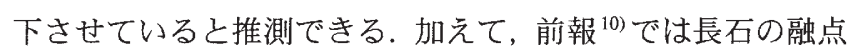
を超える温度で焼結する必要があった. 本研究で焼結原料と 
した長石は, 予め溶解処理したことで非晶質化しているので, 融点が消失している.すなわち, $1500 \mathrm{~K}$ (溶解処理前の長石 の融点) 未満での焼結にも期待できる.

\section{2 実験方法}

焼結に供した原料粉末について述べる.h-BN 粉末および 長石粉末を体積比 $1: 1$ で混合し, 焼結原料とした. h-BN 原 料としては, $\mathrm{B}_{2} \mathrm{O}_{3}$ 含有量が約 40 mass\%の高酸素h-BN粉末を 用いた. 長石原料としては, 融点が $1500 \mathrm{~K}$ 程度の曹長石 $\left(\mathrm{NaAlSi}_{3} \mathrm{O}_{8}\right)$ を加熱溶解後に冷却固化して粉砕したものを用い た. 長石溶解条件は, $1673 \mathrm{~K}-10.8 \mathrm{ks}$-炬冷 (以後, F.C.) で, 昇 温および炉冷速度はいずれも装置の制約上 $5 \mathrm{~K} / \mathrm{min}$ である. 溶解後固化した長石の粉末化は, 内径が $76 \mathrm{~mm}$ で内容積が約 $330 \mathrm{ml}$ のアルミナ容器内に長石 (加熱溶解・冷却固化済み) $80 \mathrm{~g}$ およびアルミナ球 $235 \mathrm{~g}$ (直径 $10 \mathrm{~mm}$ 球と $5 \mathrm{~mm}$ 球の混合) を 投入して密閉し, 遊星ボールミル $300 \mathrm{rpm}$ (公転速度) $-10.8 \mathrm{ks}$ の条件で, 湿式(イソプロピルアルコール)粉砕にて行った. 粉砕後に回収した長石粉末は, ロータリーバキュームエバポ レーターで乾燥させた. 以後, これを「溶解済み長石粉末」之 呼び，受入ままの「未溶解長石粉末」と区別する.なお，未 溶解長石粉末を原料としたh-BN/長石一複合体も作製し, 溶 解済み長石粉末使用の場合と比較した.

続いて, 粉末混合・圧粉・焼結の手順を述べる. 前報 ${ }^{10)}$ と 同様である. 内径が $76 \mathrm{~mm}$ で内容積が約 $330 \mathrm{ml}$ のアルミナ容 器内に, h-BN粉末 $3.63 \mathrm{~g}$ および長石粉末 $4.15 \mathrm{~g}$, アルミナ球 $235 \mathrm{~g}$ (直径 $10 \mathrm{~mm}$ 球と5 mm球の混合), イソプロピルアルコー ル $150 \mathrm{ml}$ を投入して密閉し, 遊星ボールミル $300 \mathrm{rpm}$ (公転 速度) $-3.6 \mathrm{ks}$ の条件で湿式混合処理した. その後, ロータリー バキュームエバポレーターを用いて $333 \mathrm{~K}$ 以下で乾燥させて 回収した h-BN/ 長石一混合粉末を圧粉成形に供した。内径 $\phi 15.7 \mathrm{~mm}$ の円筒形金型に h-BN/長石一混合粉末を $1.56 \mathrm{~g}$ 投入 し，ハンドプレスで $27 \mathrm{MPa}-60 \mathrm{~s}$ の室温圧粉を行った。得ら れた圧粉体の高さは6.4-6.6 mm範囲となった. 続いて, 圧粉 体をポリエチレンシート内に封入し, $200 \mathrm{MPa}-120 \mathrm{~s}$ の冷間静 水圧プレス (以後, CIP)を行った. 次に, CIP済み圧粉体を大 気中・無加圧で 1573 K-3.6 ks-F.C.の条件で焼結した。 昇温速 度および冷却速度はいずれも, 装置の制約上, $5 \mathrm{~K} / \mathrm{min}$ であ る。焼結温度は $1573 \mathrm{~K}$ および $1473 \mathrm{~K}$ の 2 種類とした。すなわ ち, 受入まま長石の融点 (約 $1500 \mathrm{~K}$ ) よりも高温および低温の 2 種類である.

次に, 粉末および焼結体の評価法を述べる. 各粉末および 各焼結体について表面のX線回折(以後, XRD)測定を行った. 焼結体の相対密度は, 焼結体かさ密度之真密度から算出した。 真密度は, 焼結体を粉砕した後, He定容積膨張法で測定した。 また, 各焼結体について, 3点曲げ試験による強度評価を行つ た. 回転砥石型精密切断機で焼結体から直方体試験片を切り 出し, 切断面の研磨を行わず, クロスヘッド速度 $0.1 \mathrm{~mm} / \mathrm{min}$ で標点距離 $10 \mathrm{~mm} の 3$ 点曲げ試験に供した。 円柱状焼結体の 高さが曲げ試験片の幅となる方向に試験片を切り出した. そ

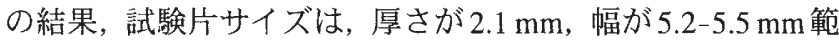
囲，長さが 12.9-13.4 mm となった。曲げ強度試験片の長手側 面(厚夕面)が, 金型圧粉成形加圧軸と垂直な関係となってい る.すなおち, 圧粉により h-BN板状粉末が配向した場合, 曲 げ試験時の長手側面とh-BN(001)䢃開面が平行となる。続い て, 曲げ試験後の焼結体について, 走査型電子顕微鏡 (以後, SEM)による破面観察を行った.

最後に, $\mathrm{h}-\mathrm{BN}$ 粉末のオージェ電子分光 (以後, AES) 分析 の手順を説明する. 高純度h-BN粉末および高酸素h-BN粉末 のいずれについても, 焼結原料と同様の未粉砕のものと, 粉 砕処理したものの 2 種類を, AES 分析に供した。粉砕処理は 下記の手順で行った．すなわち, h-BN粉末を直径 $3 \mathrm{~mm}$ のア ルミナボールおよびイソプロピルアルコールと共に「h-BN ボール $=1: 23 」 の$ 重量比でアルミナ容器内に密閉し, 遊星 ボールミル装置で $300 \mathrm{rpm}$ (公転速度) $-3.6 \mathrm{ks}$ の条件で湿式粉 砕した. そして, 各粉末について AES 分析を行った. Arイオ ンエッチングを併用して, 表面から深さ数 $\mu \mathrm{m}$ レベルの領域 まで, 順に測定した. Arイオンエッチング条件は, イオン生成 用エミッション電流 $20 \mathrm{~mA}$, イオンガン加速電压 $3 \mathrm{kV}$ とた. $\mathrm{SiO}_{2}$ 換算で $0.5 \mathrm{~nm} / \mathrm{s}$ のエッチング速度となる条件である. $600 \mathrm{~s}$ すなわち $\mathrm{SiO}_{2}$ 換算で $0.3 \mu \mathrm{m}$ エッチングする毎に測定した.

\section{3 結果および考察}

Fig. 10) $^{10)}$ ，各粉末の表面から得たXRD スペクトルを示す. 最上段の高酸素 $\mathrm{h}-\mathrm{BN}$ 粉末 ${ }^{10)}$ は, $\mathrm{B}_{2} \mathrm{O}_{3}$ 結晶相を多量に含有す ることに加えて, h-BN 結晶化が不十分であるために, 多数 のピークで構成されたスペクトルを示している. 中段の未溶 解長石粉末からのスペクトル ${ }^{10)}$ は, 長石に特有の複合酸化物 結晶相による多数のピークで構成されている. 最下段の溶解 済み長石粉末は，非晶質に特有のブロードなパターンを呈し ている. 高酸素h-BN と未溶解長石の混合粉末, 高酸素h-BN と溶解済み長石の混合粉末, それぞれについて, 金型圧粉成 形およびCIPした後, 大気中・無加圧・ $1573 \mathrm{~K}$ で焼結した.

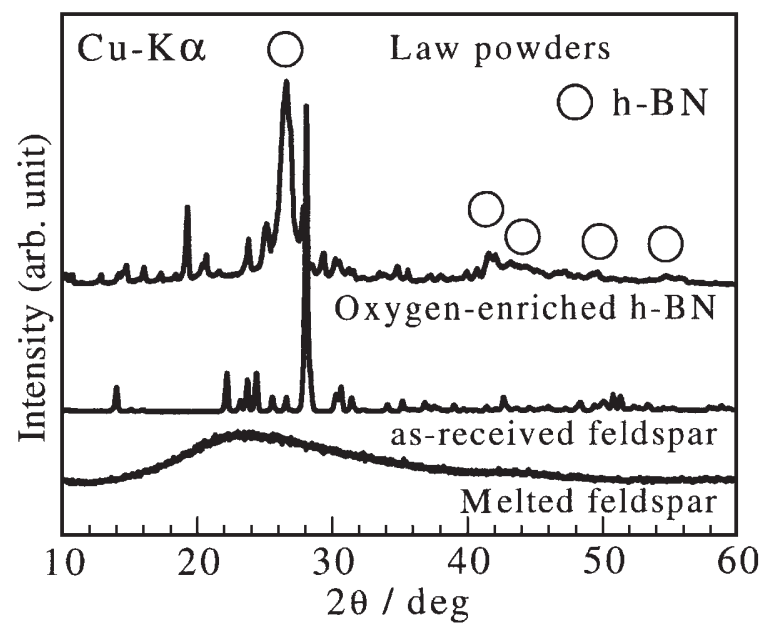

Fig.1 The X-ray diffraction spectra of the raw powders. 
Fig. $2^{10)}$ に, $1573 \mathrm{~K}$ で焼結した各h-BN/長石一複合体の表面 からのXRD 結果を示す。未溶解長石使用 ${ }^{10)}$ (上段) および溶 解済み長石使用(下段)の両焼結体において, 同様のスペクト ルが得られた. すなわち, h-BN結晶相のシャープな回折ピー クと, 溶解済み長石同様のブロードなパターンの, 2 種類で 構成されている. その理由としては, 下記のように考察でき る. 高酸素 h-BNについては, 焼結過程の昇温により, $\mathrm{B}_{2} \mathrm{O}_{3}$ が溶融して非晶質化することに加えて, h-BN 結晶化が完了 する.また, 未溶解長石を焼結原料とした場合であっても, 焼 結温度が長石の融点を超えているので, 長石は昇温過程で溶 解して冷却・固化した後も非晶質を保つ. したがって, 焼結 前に存在した高酸素 $\mathrm{h}-\mathrm{BN}$ 粉末の $\mathrm{h}-\mathrm{BN}$ 結晶相以外の多数の ピーク, および, 未溶解長石の複合酸化物結晶相ピークは, 焼 結により消失する ${ }^{10)}$.

Fig. $3^{10)}$ に, 各焼結体の外観を示す。いずれの焼結体も, 焼 結前 (CIP後) と同様の形状をしており, 型崩れは起こしてい

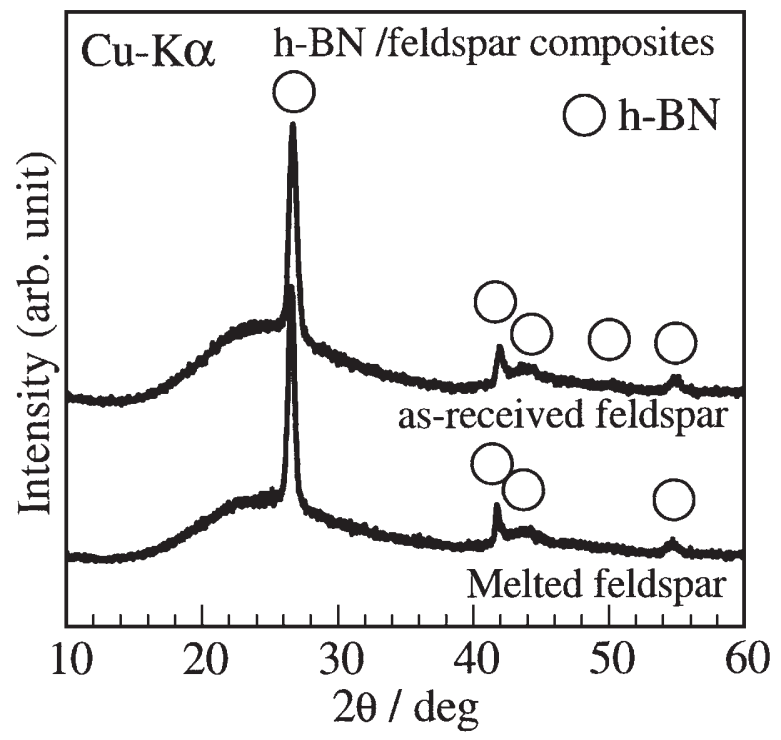

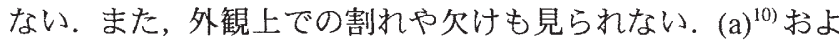
び (b) は $1573 \mathrm{~K}$ で焼結した焼結体である．相対密度は，(a)の 未溶解長石使用焼結体 ${ }^{10)}$ が $81 \%$ ，(b) の溶解済夕長石使用焼 結体が $84 \%$ であった。(a)の末溶解長石使用 ${ }^{10)}$ の方が, (b) の 溶解済夕長石使用に比べて, 焼結体表面に見られる空隙が明 らかに大きくかつ多い。未溶解長石使用の場合, 長石溶融に 伴うガス成分放出が焼結中に起こり，そのことが緻密化疎外 の要因になったと考えられる。一方, 溶解済み長石使用の場 合は, 前処理でガス成分放出を済ませた長石を焼結原料とし ているので, 焼結中には長石からのガス放出はほとんどなく， 緻密な焼結体が得られたと考えられる.

Fig.3 (c) は, 高酸素h-BN/溶解済み長石一混合粉末を $1473 \mathrm{~K}$ で焼結した複合体である.未溶解長石は結晶状態であり，そ れを焼結原料としてバインダーの機能を持たせるためには， 融点を超える温度で焼結する必要があった。しかしながら， 溶解済み長石は非晶質で融点を消失しており，それを原料と する場合は, 必ずしも元の融点を超える温度で焼結する必要 はない. 本研究の焼結温度は $\mathrm{B}_{2} \mathrm{O}_{3}$ の蒸発開始温度を大幅に超 えている.すなおち, 焼結過程で $\mathrm{B}_{2} \mathrm{O}_{3}$ が大量に蒸発・消失し ている可能性がある. $\mathrm{B}_{2} \mathrm{O}_{3}$ 蒸発・消失が生じている場合は, 焼結温度が低いほど, $\mathrm{B}_{2} \mathrm{O}_{3}$ 蒸発量が少なく焼結体強度確保に 有効なはずである。 あるいは，h-BN/ 長石一界面の $\mathrm{B}_{2} \mathrm{O}_{3}$ が, 焼結過程で溶融長石内部に吸収されて, 時間と共に界面から 減少する可能性もある，その場合も，溶融長石の温度が低く 粘性が高い方が, 焼結体強度確保には有利なはずである.ま た，本実験においては，昇温および冷却速度が $5 \mathrm{~K} / \mathrm{min}$ であ るので, 焼結温度が $100 \mathrm{~K}$ 低いことは, 高温に保持される時 間が $2.4 \mathrm{ks}$ 短いことを意味する. そのことも焼結体強度確保 に有利に働くはずである，そこで, 未溶解長石の融点よりも 低い $1473 \mathrm{~K}$ での焼結を行つた. $1573 \mathrm{~K}$ 焼結体(b)に比べて $1473 \mathrm{~K}$ 焼結体 (c) は, 円周エッジ部のダレがない。相対密度は $85 \%$ であった。

Fig.2 The X-ray diffraction spectra of the composites.

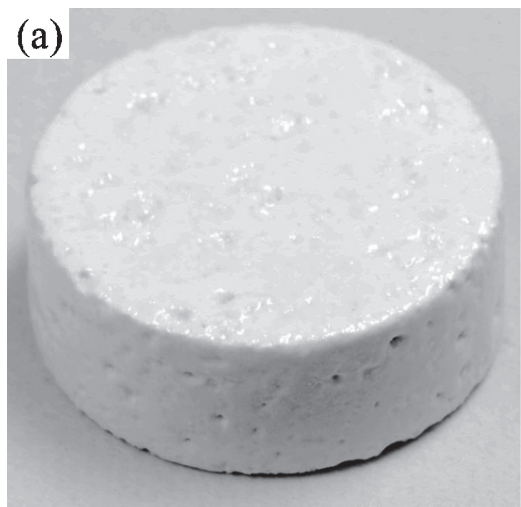

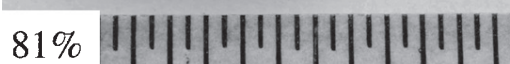

(b)

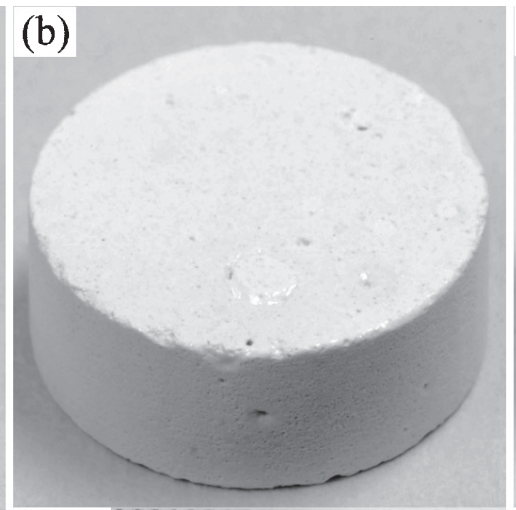

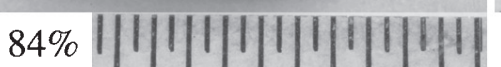

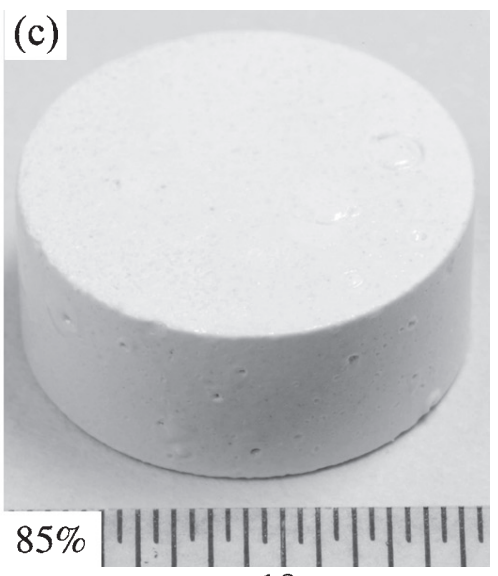

$10 \mathrm{~mm}$

Fig.3 The external appearances of the composites. (a) Sintered at $1573 \mathrm{~K}$ using as-received feldspar, (b) Sintered at $1573 \mathrm{~K}$ using melted feldspar, (c) Sintered at $1473 \mathrm{~K}$ using melted feldspar. 
Fig.4に, 各焼結体の断面 SEM 二次電子像を示す. (a) およ び(b)は $1573 \mathrm{~K}$ 焼結体, (c) は $1473 \mathrm{~K}$ 焼結体であり, それぞれ Fig.3 (a) (b) (c)に対応している.いずれの断面もダイヤモンド 研磨剂で研磨・玩磨した結果であるが, 研磨時の母材脱落に よる篗みが見られる。この観察結果からは, h-BN粒子界面は 見出せず，また，h-BNと長石の区別もつけられない. なお， 反射電子像においても, h-BN と長石を区別できる濃淡は観 察されず, Fig.4に示した二次電子像と同様の情報しか得られ なかった.

Fig. $5^{10)}$ に，各焼結体の 3 点曲げ試験結果を示す．比較のた め, 高純度 $\mathrm{h}-\mathrm{BN} /$ 未溶解長石一複合焼結体の結果 ${ }^{10)}$ も示した
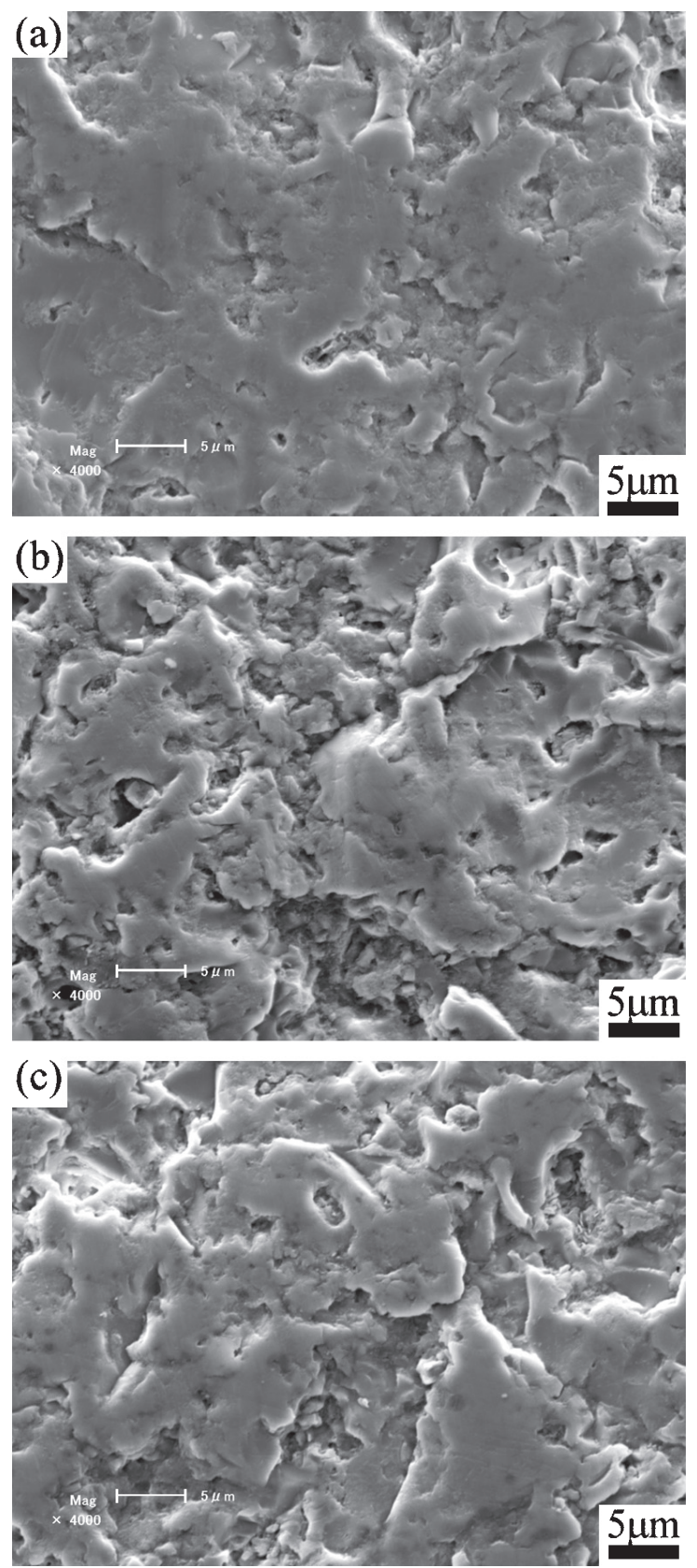

Fig.4 The cross sections of the composites. (a) Sintered at 1573 $\mathrm{K}$ using as-received feldspar, (b) Sintered at $1573 \mathrm{~K}$ using melted feldspar, (c) Sintered at $1473 \mathrm{~K}$ using melted feldspar.
(左端)、図において, 左から 3 本は $1573 \mathrm{~K}$ 焼結体の結果であ る. 曲げ強度は, 高純度 h-BN/未溶解長石一焼結体 (左端)が $8 \mathrm{MPa}$, 高酸素 $\mathrm{h}-\mathrm{BN} /$ 未溶解長石一焼結体 $(\text { 左から } 2 \text { 本目 })^{10}$ が $47 \mathrm{MPa}$ である. これら左 2 本から, 高酸素 h-BN粉末使用 の有効性が確認できる ${ }^{12}$. 続いて, 高酸素 h-BN/ 溶解済み長 石一焼結体 (左から 3 本目)では $54 \mathrm{MPa}$ となった. すなわち, 長石に前処理溶解を施すことで, 焼結体の曲げ強度をさらに 1 割程度増すことができた。 上述した通り，長石溶融に伴う ガス放出を前処理で完了させた効果と考えられる. Fig.5の右 端は $1473 \mathrm{~K}$ 焼結体である. 高酸素 $\mathrm{h}-\mathrm{BN} /$ 溶解済み長石一混合 粉末を $1473 \mathrm{~K}$ で焼結したところ, 曲げ強度 $59 \mathrm{MPa}$ の焼結体 を得た。焼結温度を $100 \mathrm{~K}$ 下げて, 受入まま長石の融点より も低い $1473 \mathrm{~K}$ とすることで, 焼結体の曲げ強度をさらに 1 割 程度增すことができた。

ところで, 焼結において十分な界面濡れを確保するために は, $\mathrm{B}_{2} \mathrm{O}_{3}$ が高酸素 $\mathrm{h}-\mathrm{BN}$ 粉末の表面のみならず内部にまで均 一に分散している必要がある. h-BN/長石一複合焼結体の製 造プロセスには, h-BN粉末と長石を混合する工程がある.こ の混合工程で h-BN 粉末は粉砕される可能性が高い. 焼結に 最適な粒度分布とするために粉砕処理を混合前に行う場合も 想定される. すなわち, h-BN 受入材粉末の表面のみに集中 的に $\mathrm{B}_{2} \mathrm{O}_{3}$ が存在する形態では, 粉砕で新生面の割合が増した 場合に, 焼結時の濡れ性が失われる. 一方で, 通常市販され ている低純度 $h-B N$ 粉末 $\left(\mathrm{B}_{2} \mathrm{O}_{3}\right.$ 濃度が数\%程度) は, $\mathrm{B}_{2} \mathrm{O}_{3}$ のほ とんどが粉末表面に分布していると推測できる. $\mathrm{B}_{2} \mathrm{O}_{3}$ が水溶 性であることを利用して, h-BN 粉末を水中に浸漬した後に 乾燥させることで, 表面の $\mathrm{B}_{2} \mathrm{O}_{3}$ を除去して $99 \%$ 以上の高純

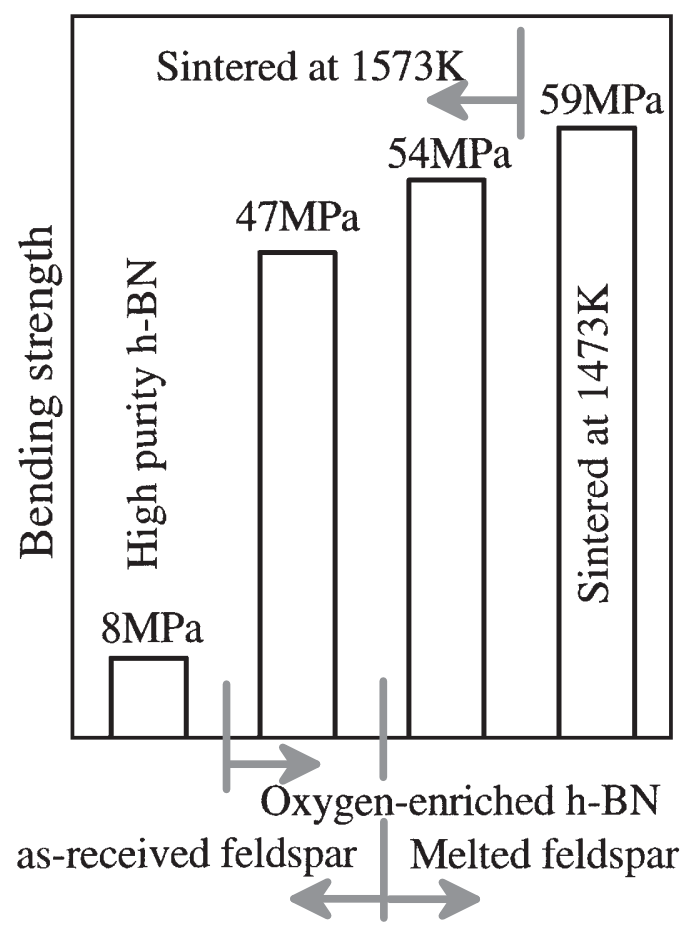

Fig.5 The bending strength of the composites. 


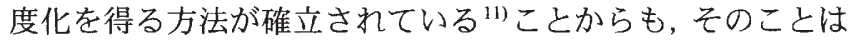
予測できる. 加えて, h-BN/長石一複合焼結体の製造におい て, h-BN粉末・長石粉末 $\cdot \mathrm{B}_{2} \mathrm{O}_{3}$ 粉末の3 者を混合しても, 添 加 $\mathrm{B}_{2} \mathrm{O}_{3}$ 粉末は焼結中に溶融長石に吸収されてしまい, h-BN/ 長石一界面の濡れに関与できないことは, 容易に推測できる. $\mathrm{B}_{2} \mathrm{O}_{3}$ は単独でなく h-BN 粉末と一体で存在する必要がある.

Fig.6に，受入まま(未粉砕) 高純度 h-BN 粉末の AES 結果 を示す. 縦軸は, オージエ電子の検出カウント数を運動エネ ルギ一值で微分した值で示した. 粉末表面のAES結果を最上 段に示した. 2段目以降は, 粉末試料表面を Arイオンで $600 \mathrm{~s}$ $\left(\mathrm{SiO}_{2}\right.$ 換算で $\left.0.3 \mu \mathrm{m}\right)$ エッチングする毎にAES測定した結果を, 通算 $1.2 \mathrm{ks}\left(\mathrm{SiO}_{2}\right.$ 換算で $\left.0.6 \mu \mathrm{m}\right)$ エッチングした分まで示した. $\mathrm{B}$ と $\mathrm{N}$ は, 当然ながら表面から全測定媣さまで明瞭に検出さ れた. Oは, 粉末表面からもエッチング深さ領域からも検出 されなかった. 高純度h-BN 粉末は, 表面においても内部に おいても, $\mathrm{B}$ 原子および $\mathrm{N}$ 原子で構成され, O原子は (AESで 検出できるレベルには) 存在していない, すなわち, 高純度
h-BN粉末には $\mathrm{B}_{2} \mathrm{O}_{3}$ が(AES で検出できるレベルには)存在し ないことがFig.6からわかる. なお, 粉砕処理後の高純度h-BN 粉末についても, Fig.6と同様の結果を得た.

Fig.7に, 粉砕処理後の高酸素h-BN粉末の AES 分析結果を 示す. $\mathrm{Ar}$ イオンエッチング $3.0 \mathrm{ks}$, すなわち $\mathrm{SiO}_{2}$ 換算で $1.5 \mu \mathrm{m}$ の深さまでエッチングを行い, 測定した。 $\mathrm{B}$ と $\mathrm{N}$ は, 当然な がら表面から全測定深さまで明膫に検出された. 加えて, 表面 にもエッチング深さ領域にも，Oが明瞭に検出された。この 試料は焼結原料である h-BN 粉末を粉砕して新生面を露出さ せたものである.その試料から Oが多量に検出されたこと は, 粉砕前の原料粉末の内部にも Oが存在したことを意味す る. 高純度 h-BN粉末を粉砕した後にAES 測定した結果にお いて Fig.6同様にOが検出されなかつたことから, Fig.7にお けるO検出は粉砕処理過程での酸化によるものではない. $\mathrm{O}$ 原子が h-BN 結晶内に大量固溶しているとは考え難いので, 高酸素 h-BN 粉末においては粉末表面のみならず内部にも一 様に $\mathrm{B}_{2} \mathrm{O}_{3}$ が分布していると判断できる. なお, 受入まま (未
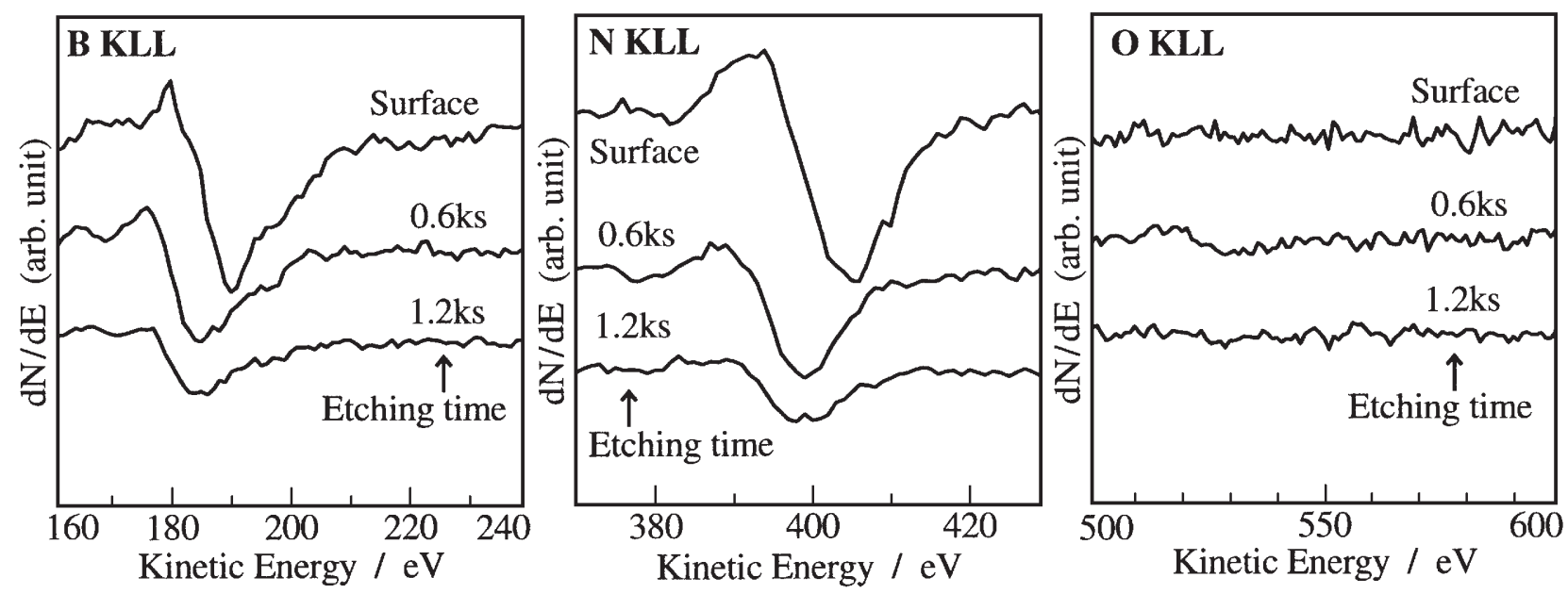

Fig.6 The Auger electron spectroscopy of the as-received high purity h-BN powder.
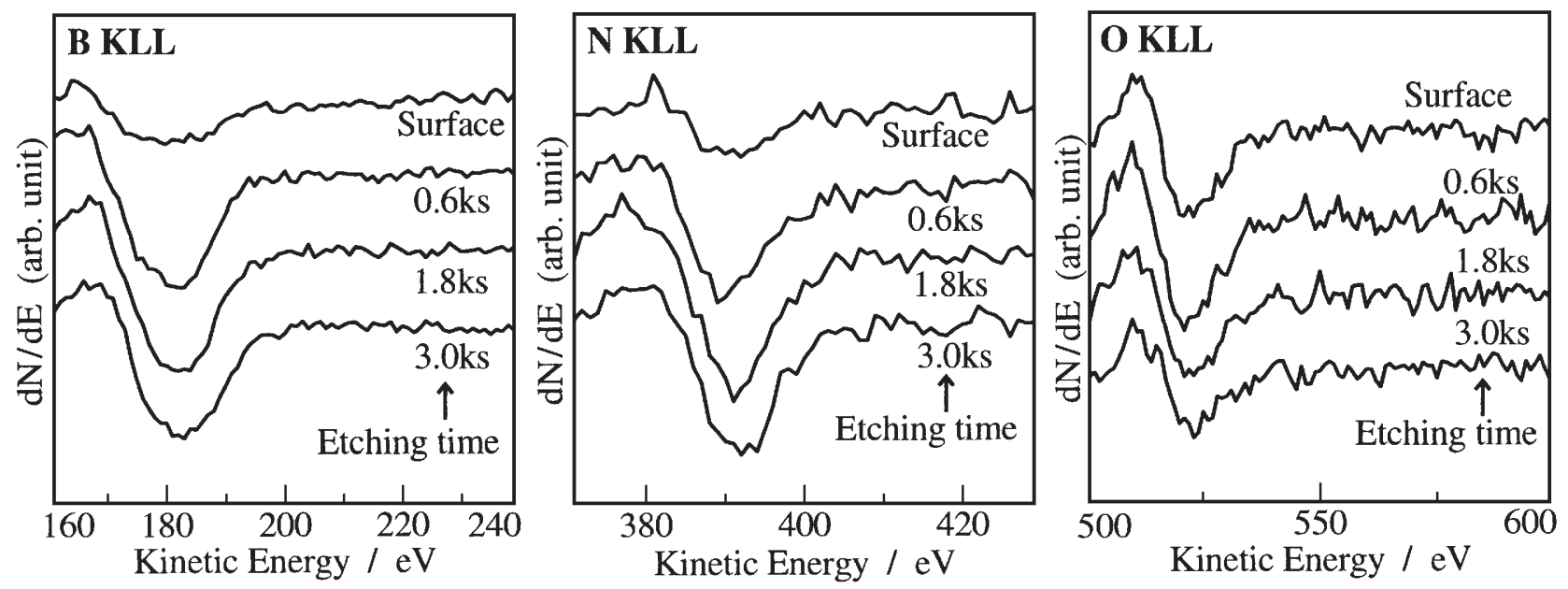

Fig.7 The Auger electron spectroscopy of the oxygen-enriched h-BN powder as milled. 
粉砕) 高酸素 h-BN 粉末についても, Fig.7 と同様の結果を得 た.

\section{4 結 言}

h-BN/長石一複合体の大気中・無加圧・低温焼結において, 長石原料に前処理を施すことで, 焼結体の強度向上を目指し た. 具体的には, 長石を加熱溶解後に冷却固化して粉砕し,こ れを高酸素 h-BN 粉末 (約 40 mass\% の $\mathrm{B}_{2} \mathrm{O}_{3}$ を含有) と体積比 1:1の割合で混合して焼結に供した. そして, 未溶解長石を 原料とした場合と比較した. その結果, 以下の知見を得た. 長 石の融点を超える $1573 \mathrm{~K}$ で焼結する場合, あらかじめ溶解済み の長石粉末を用いることで, 未溶解長石を用いる場合よりも, 焼結体曲げ強度が約 1 割程度増す。また, 非晶質化で融点を 消失させた溶解済み長石を用いることで, 受入まま長石の融 点よりも低い $1473 \mathrm{~K}$ で焼結することが可能となる. しかも, $1573 \mathrm{~K}$ 焼結体に比べて $1473 \mathrm{~K}$ 焼結体は, さらに1割程度高い $59 \mathrm{MPa}$ の曲げ強度を持つ. また, 本研究に用いた高酸素h-BN 粉末は, 表面のみならず内部にも同様に $\mathrm{B}_{2} \mathrm{O}_{3}$ を含有してい る.

本研究は, 名古屋市事業「サイエンスパーク研究成果活用 型共同研究開発」として遂行した.h-BN原料粉末の組成 $\left(\mathrm{B}_{2} \mathrm{O}_{3}\right.$ 量) 分析值は, 東海無機分析化学研究会 2008 年度共同分析に おける結果である.

\section{文献}

1) D.A. Lelonis: "Boron Nitride - a review", Ceramic Technology International 1994, Sterling Publishing Group PLC, (1994)5761 .
2) D.A. Lelonis: "Boron Nitride Tackles the Tough Ones", Ceramic Industry, (1989)57-60.

3) A. Lipp, K.A. Schwetz, and K. Hunold: "Hexagonal Boron Nitride: Fabrication, Properties and Applications", Journal of the European Ceramic Society, 5(1989) 3-9.

4) D.P.H. Hasselman: "Thermal Stress Resistance Parameters for Brittle Refractory Ceramics: A Compendium", Ceramic Bulletin, 49(1970) 1033-1037.

5) M. Ishii: "Physical Properties and Uses of the Boron Nitride as New Ceramics", Ceramics Japa, 5(1970)467-475.

6) M. Fujio: "Boron Nitride", Kougyouzairyou, 28(5) (1980)2125,52 .

7) H. Nishikawa and H. Yasunaga: "Remarkable high heat conductive ceramics. Examples. BN ceramics", Kougyouzairyou, 36(15) (1988) 54-60

8) J. Eichler and C. Lesniak: "Boron nitride (BN) and BN composites for high-temperature applications", Journal of the European Ceramic Society, 28(2008) 1105-1109.

9) S. Kume, S. Saklar, and K. Watari: "Consolidation of h-BN/ feldspar Composites in Air", Advanced Material Research, 11-12(2006)429-432.

10) M. Hashii, H. Yamada, and S. Kume: "Effect of Using Oxygenenriched h-BN Powder for the Property of h-BN/Feldspar composite", in this issue.

11) T. Funahashi, T. Koitabashi, R. Uchimura, T. Koshida, A. Yoshida, and T. Ogasawara: "Development and Application of High-Purity Hexagonal Boron Nitride (h-BN) Powder", Kawasaki Steel Giho, 24(1992)135-141. 